UDC 796.032.2.063.4

http://doi.org/10.21272/mmi.2019.1-29

JEL Classification: C12, M38

Volodymyr Prykhodko,

D.Sc., Professor, Pridneprovsk State Academy of Physical Culture and Sports, Ukraine

Oleksandr Tomenko,

D.Sc., Professor, Sumy State Pedagogical Makarenko University, Ukraine

\title{
INNOVATIVE APPROACH TO THE STRATEGIC MANAGEMENT OF THE OLYMPIC SPORT REFORM IN UKRAINE
}

\begin{abstract}
The main goal of the paper is to justify the implementation of the innovative approach to the strategic management from the Ministry of Youth and Sport of Ukraine during preparation and realization of the reform regarding the sportsmen's training system in the Olympic sports. Authors defined the necessity to use the innovative managerial approach to regulate the Olympians' training system in Ukraine. It was proved that the current system could not effectively function owing to the current stable negative tendency regarding Ukrainian sportsmen's performance results in Summer and Winter Olympic Games (in several times during 1996-2016). Considering the ongoing issues, the implementation of «Strategy to form the modern system of the Olympic training for the period up to 2020» should provide the change of the whole paradigm regarding the impacts on the sporting sphere in the leading authorities of state administration. One the hypothesis of the paper was checking the direct cause-effect relationship between economic growth and number of the Ukrainian sportsmen's victories in the Olympic Games. The results of the regressive analysis regarding the relationship between GDP per capita growth (annual \%) and medal points in Olympic disciplines for Ukraine during 1994-2016 proved the absence of the direct and statistically significant dependence between these two indicators. Within the framework of the innovative approach, authors proposed: to distribute functions on sport development management in the centre and at the local level; to introduce the practice to develop managerial decisions regarding experts' involvement; to create new organization forms of the modern sport, such as training centres; to investigate and to use instruments of the macro pedagogical impact on the sportsmen's training practice in districts, in Kyiv and in the national federations.
\end{abstract}

Keywords: innovative approach, strategic management, high-level sport, Olympic sport, the system of sportsmen's training.

Introduction. Under conditions of globalization and integration of the national economy, its competitiveness growth is supposed to be the main condition for functioning and successful achievement in the modern world. That is why one of the main tasks of the Sustainable Development Strategy «Ukraine2020 » is to provide the country's competitiveness level increase at the level of 40 best state in the world. The development of sport as the state policy priority is mostly characterized by the possibility for the country's economic growth and its competitiveness increase. Particularly, the Olympic Games in London 2012 had an unprecedented character of the social, political and economic mobilization (Girginov and Hills, 2008). It provided the increase of GDP per capita (US\$) to the level 38.589 and of the Global Competitiveness Index in Great Britain - 5.4 (10th place among 148 countries of the world). Besides, as the authors of the work mention (Lyulyov, 2018), the formation of the country's brand based on the sport marketing companies will provide the great influx of tourists and investment in the sports sphere. It will cause the long-term economic growth of the national economy. In Spain, the sports sector provides $1 \%$ of the GDP of this country.

In the super complex problem regarding the Olympic sport reform in Ukraine, there are two obvious aspects. The practical aspect, which is felt even by an average citizen, consists in the fact that Ukraine is not satisfied with more than modest medal success of the Ukrainian Olympians in Summer and Winter Sports. Therefore, despite the assurance of the domestic sport leaders that everything will be fine soon, the further, the less. The theoretical aspect of the problem, which is obvious for scientists and specialists, who are experienced in the sporting sphere, is remarkable by the limitation of the theoretical knowledge

Cite as: Prykhodko, V., \& Tomenko., O. (2019) Innovative Approach to the Strategic Management of the Olympic Sport Reform in Ukraine. Marketing and Management of Innovations, 1, 357-366. http://doi.org/10.21272/mmi.2019.1-29 
(conceptions, impact instruments, as effective instruments to form the effective system for sportsmen's training). Obviously, the practical aspect is a part of the reform problem, which depends on a proactive solution of the theoretical aspect. Otherwise, sports reform is impossible until theoretical issues will not be solved.

Literature Review. Nielsen K. and Storm R. K. (2013) in their work «ls India the Exception?: The Impact of Economic Growth on the Competitiveness of National Elite Sport Systems» make a hypothesis that there is a direct cause and effect relationship between the country's economic growth and its sports success on the international stage. However, the carried-out correlation analysis proved that the link is at best indirect, and highly dependent on several intervening or mediating variables. The efficiency of state regulation plays a significant role in the setting of the statistically essential and positive relationship between economic growth and victories increase in the Olympic Games. Moreover, despite the economic growth and competitiveness level increase in India, this relationship has not been confirmed. Scientists explain that it occurs because of the lack of political commitment and managerial inefficiency. While studying the professional sports teams influence on the cities' economic development, Baade R. A. (1996) made a conclusion that expenses for such teams which the cities' authorities face in the USA are facing an unprecedented number of threats. Therefore, the authors notice that in order to involve and to save the team, cities suggest great financial support, where the main beneficiaries of subsidies are owners and players, but not taxpayers.

According to the studies of Manzenreiter W. and Horne J. (2005), the introduced national sports system plays a significant role to counteract the extension of the gap between centre and periphery in Japan. In addition, the efficiency of the national sports system promotes the transformation and strengthening of civil valuables and beliefs in the country (Johnson, 1982).

Methodological principles and peculiarities of innovations introduced in organizations and territories were revealed by V. S. Boichenko (2017), O. S. Hrynkevych, N. P. Lutchyn (2017). H. M. Zakharchyn, T. V. Sklyaruk (2017). N. R. Kordzaya (2017) focused their attention on the transformation of modern valuables to the management category. They are able to orient to the spiritual and social aspect of human development, the important place among which is taken by sport and its acceptance from the viewpoint of social advertisement in the modern world. H. S. Bordyugova (2009)], G. O. Garo and O. O. Kushnir (2016) focused their attention on the place and implementation of the sports law in the national legal system. S. V. Volik (2013) revealed peculiarities of the sport financing under modern conditions. T. K. Yesentayev (2016), V.M. Platonov $(2015,2012)$ and H. Sozanski (2003) studied the aspects of high-qualified sportsmen's training. V. V. Prykhodko justified the necessity to implement the way to manage the projects in the ongoing sport (2014) and investigated the perspectives to use the program-based management of the sports development in cities and districts (2017). The conception of the current system regarding the Olympic athletes' training in Ukraine and its implementation mechanism of the specific «spherical» innovative process have not been formed yet. After Winter Olympiad in Salt Lake City in 2002, it was noticed that one of the most serious causes of the Ukrainians' unsuccessful performances in the Olympic Games includes the absence of the development strategy regarding winter Olympic sports (although this fault relates to all Olympic sports without any exception). It was pointed out that it is shown in the weak coordination regarding actions of National Olympic Committee, federations, central and local authorities of the physical culture and sport development, sports unions, i.e. all main organizers of the Olympiads. The absence of the strategy and clear distribution of powers and functions do not let to unite efforts and possibilities to provide more effective preparation to Games (Platonov et al, 2012). At the same time, attention was paid to the necessity to study and to use the significant experience regarding the organization of the sportsmen's training system, accumulated abroad (Bordyugova, 2009; Volik, 2013; Garo and Kushnir, 2018; Esentaev, 2016; Sozansky, 2003). Besides, the implementation of the concept 
«strategic management» in the context of the urgent reform regarding Olympians' training is paid special attention.

The aim of the article is to justify the necessity in the innovative approach to the strategic management on the part of Ministry of Youth and Sport of Ukraine during the preparation and introduction of the reform regarding the system to train sportsmen in the Olympic sports.

Results. The term «strategic management» was introduced during the end of the 1960s - at the beginning of 1970 s to reflect the difference in management, performed at the highest level, from the current management at the organization level (in this case - sport). The necessity to introduce such difference serves, first of all, to changes in the environment. As a leading idea which reflects the essence of transition from operative to strategic management, there was an idea about the necessity to focus attention by senior leaders on the environment in order to respond to changes that occur in some way and in time, to respond to challenges in the environment.

In relation to the Olympic sports, changes in the environment consist in the continued change in countries, which are responsible for the participation of all elements in the sportsmen's training system in the Olympic Games, with the purpose to implement current possibilities to improve sport results. Strategic management can be defined as an administration, which is based on human potential. It orients «the producing» activity to consumers' requests (i.e., participants of the sports training process), performs the flexible regulation and well-timed changes, which comply with the challenge from the environment and enable to have competitive advantages, which let to achieve the aim regarding the sportsmen's training in the long-term perspective. Although strategic management is the most significant factor of the success in the competition in high sport, one can observe the absence of strategy inactions of the Ministry of Youth and Sport of Ukraine. It often defines defeats at the largest international competitions. The absence of strategic management is shown in two forms.

First, the activity is planned according to realizing that the environment either will not be changed at all, or there will not be any qualitative changes. In the «nonstrategic» management there is a plan of concrete actions for the current time and for future since this style of management is a priori based on the assumptions that the environment (the Olympic sports world) will not be practically changed.

Thus, a long-term perspective vision is an important constituent of management in the Olympic sport sphere. Such an approach should not be the extrapolation of the current practice and state in the environment of the whole Olympic cycle in the medium-term perspective. In the strategic management, every moment fixes what the organization (in this case the highest authorities) has to do at this time, in order to achieve the desired goals in future, considering the fact that the environment and existence conditions of the sport will be constantly changed. It means that the strategic management does not use the logic «from here and in advance», but «view from future to today's life». In such a way one can define and carry out the actions of the organization at this time, providing us with a successful future. The strategic management is characterized with the fact that not only optimal state of our sport is fixed, but it is an important task of the strategic management and the ability to respond to changes in the environment is produced.

Second, in nonstrategic management, the actions program is produced by the analysis of the internal abilities and resources of the organization. According to such approach everything that can define by the organization on the basis of its internal abilities' analysis, is the fact that one can do and what costs it can accomplish. In fact, the sportsmen's training practice and costs for them will not give an answer for the main question, how competitive the created product is, the contest will define.

As for the necessity to carry out the reform, it is pointed out the following fact. The medal achievements, referring to results of Ukraine's participation in the Olympic Games during its independence (Shynkaruk, 2012) (Table 1 and 2). 
Table 1. Medals, conquered by Ukraine in the Summer Olympic Games

\begin{tabular}{|l|c|c|c|c|c|}
\hline \multicolumn{1}{|c|}{ Games } & Gold & Silver & Bronze & Total & Place \\
\hline 1996, Atlanta & 9 & 2 & 12 & 23 & 9 \\
\hline 2000, Sydney & 3 & 10 & 10 & 23 & 21 \\
\hline 2004, Athens & 8 & 5 & 9 & 22 & 13 \\
\hline 2008, Peking & 7 & 4 & 11 & 22 & 11 \\
\hline 2012, London & 6 & 4 & 10 & 20 & 14 \\
\hline 2016, Rio-de-Janeiro & 2 & 5 & 4 & 11 & 31 \\
\hline \multicolumn{1}{|c|}{ Total } & 35 & $\mathbf{3 0}$ & $\mathbf{5 6}$ & $\mathbf{1 2 1}$ & 32 \\
\hline
\end{tabular}

Source: developed by the author.

Statistic data prove that according to the number of gold medals (dominating indicator), and according to the total number of medals, Ukraine loses its positions: if one counts gold medals, it is the main indicator, it is four and half times. This tendency is confirmed by results of the statistical analysis regarding the chain growth rate by indicators of the conquered medals by the Ukrainian sportsmen in the Olympic Games during 1996-2016 and places of Ukraine in the total medal count.

Table 2. Medals, conquered by Ukraine in Winter Olympic Games

\begin{tabular}{|l|c|c|c|c|c|}
\hline \multicolumn{1}{|c|}{ Games } & Gold & Silver & Bronze & Total & Place \\
\hline 1994, Lillehamer & 1 & 0 & 1 & 2 & 13 \\
\hline 1998, Nagano & 0 & 1 & 0 & 1 & 18 \\
\hline 2002, Salt-Lake-City & 0 & 0 & 0 & 0 & - \\
\hline 2006 pik, Turin & 0 & 0 & 2 & 2 & 25 \\
\hline 2010, Vancouver & 0 & 0 & 0 & 0 & - \\
\hline 2014, Sochi & 1 & 1 & 0 & 2 & 20 \\
\hline 2018, Pyeongchang & 1 & 0 & 0 & 1 & 21 \\
\hline \multicolumn{1}{|c|}{ Total } & $\mathbf{3}$ & $\mathbf{2}$ & $\mathbf{3}$ & $\mathbf{8}$ & $\mathbf{3 3}$ \\
\hline
\end{tabular}

Source: developed by the authors.

According to the number of medals, the negative rate of growth after 2008 (from 0.91 to 0.55 ), before which there was a stable period from 1996 to 2008, caused by the active exploitation of traditions and technologies to control the Olympians' training in the USSR, which lose their efficiency under modern conditions. The analysis of the chain growth rate of Ukraine's place in the total medal count during 19962016 showed its wavelike dynamics with highly reliable $(p<0.01)$ reduction as a result of the Olympic Games - 2016, that also confirms the inefficiency of the Olympic sport management system in Ukraine.

Noted, that success in 1996 connect with the previous system of the sportsmen's training, formed in the USSR. The thirty-first place after Rio de Janeiro is the biggest failure of Ukraine during its independence. It is identified by the absence of the qualitative system to train Olympians, formed during its independence. Thus, this responsible and professional work was not carried out over more than 20 years. It enables to predict that if such a state remains the same further, the medal results will not be improved.

The absence of the Ukrainian athletes' progress from one Winter Olympiad to another is remarkable from Table 2. If one takes into account sports in which athletes won medals, it will be shown in the following way (Table 3 and 4). 
Table 3. Medal achievements of the Ukrainian team (by kinds of sport) In the Summer Olympic Games

\begin{tabular}{|l|c|c|c|c|}
\hline \multicolumn{1}{|c|}{ Sport } & Gold & Silver & Bronze & Total \\
\hline Gymnastics & 7 & 4 & 8 & 19 \\
\hline Boxing & 4 & 3 & 7 & 14 \\
\hline Swimming & 4 & 2 & 1 & 7 \\
\hline Shooting & 4 & 2 & 2 & 8 \\
\hline Wrestling & 3 & 6 & 6 & 15 \\
\hline Rowing and canoeing & 3 & 2 & 3 & 8 \\
\hline Weightlifting & 3 & 1 & 2 & 6 \\
\hline Athletics & 2 & 2 & 12 & 16 \\
\hline Fencing & 2 & 1 & 3 & 6 \\
\hline Sailing & 1 & 2 & 2 & 5 \\
\hline Archery & 1 & 1 & 2 & 4 \\
\hline Academic rowing & 1 & 1 & 1 & 3 \\
\hline Cycling & 0 & 1 & 2 & 3 \\
\hline Judo & 0 & 1 & 2 & 3 \\
\hline Modern pentathlon & 0 & 1 & 0 & 1 \\
\hline Jumping in the water & 0 & 0 & 2 & 2 \\
\hline Handball & 0 & 0 & 1 & 1 \\
\hline \multicolumn{1}{|c|}{ Total } & 35 & 30 & 56 & 121 \\
\hline
\end{tabular}

Source: developed by the author.

As it is seen over 20 years of participation in the Summer Olympic Games sportsmen from Ukraine won medals only in 17 sports (therefore considering athletes' successes in different kinds of wrestling). Besides, it is possible to distinguish 17 types of and those where Ukraine won gold medals. In fact, they include those sports, in which Ukraine has the best traditions and potential for further development. Obviously, in the current conditions, every district has sportsmen, who have a good perspective for future Olympic Games, that must be considered.

Table 4. Medals of the Ukrainian team (by the sports) in the Winter Olympic Games

\begin{tabular}{|l|c|c|c|c|}
\hline \multicolumn{1}{|c|}{ Sport } & Gold & Silver & Bronze & Total \\
\hline Figure skating & 1 & 0 & 1 & 2 \\
\hline Biathlon & 1 & 1 & 3 & 5 \\
\hline Freestyle & 1 & 0 & 0 & 0 \\
\hline Total & $\mathbf{3}$ & $\mathbf{1}$ & $\mathbf{4}$ & $\mathbf{8}$ \\
\hline
\end{tabular}

Source: developed by the author.

As for the winter sports, success in figure skating and freestyle relate to the single, non-systemic achievement. The reliable medal perspectives of Ukraine first of all relate to the biathlon. Everyone knows the consequent, perspective-oriented work of the National Biathlon Federation.

Thus, more modest medal success of Ukraine in every Olympic cycle and absence of the qualitative transformations in the system regarding Olympians' training require objectively the qualitative and operative deployment of the sportsmen's training modern system in summer and winter Olympic sports.

In the last decade, the Ukrainian economy entered the period of swift fluctuations in the economic growth rates that greatly influenced the possibility to introduce additional investment in the national sports 
system. The results of the regressive analysis regarding the relationship between GDP per capita growth (annual \%) (var 2) and medal points in Olympic disciplines (var 3) for Ukraine during 1994-2016 proved the absence of the direct and statistically significant dependence between these two indicators.

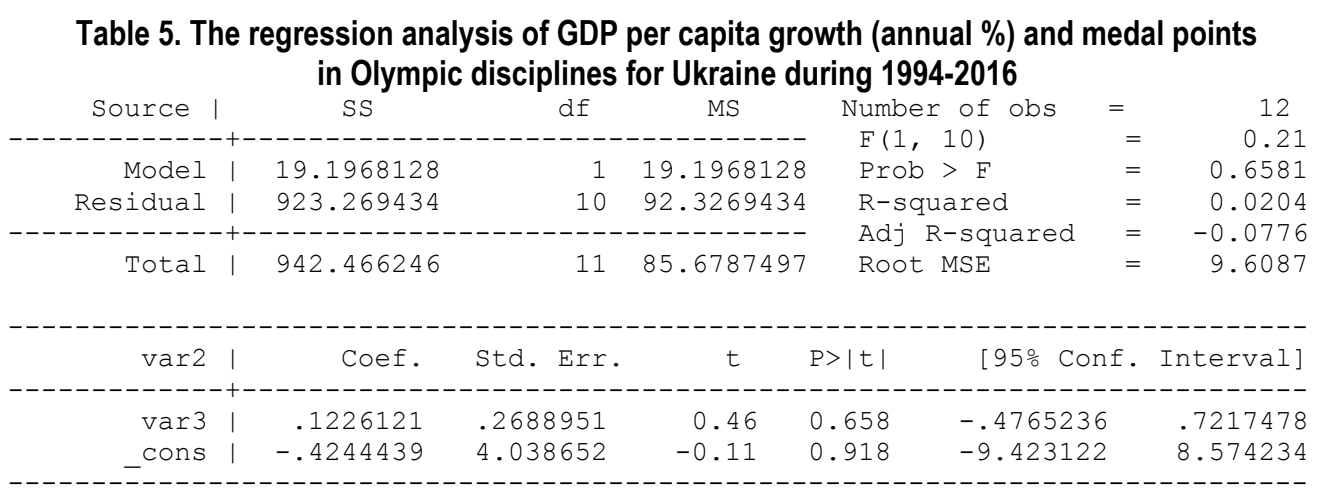

Note: authors calculations based on the World Bank, estimated with Stata 14.0.

Source: developed by the author.

Ministry of Youth and Sport of Ukraine tries to act since it understands the ways to overcome this situation. It is known that there was a Strategy of the Olympic Preparation Modern System for the period till 2020, approved by the resolution given by the Cabinet of Ministers of Ukraine from 3.06.2009 № 592-p. The Order № 2392 from 15.06.2012, given by the Ministry of Youth and Sport of Ukraine, registered in the Ministry of Justice of Ukraine 5.07.2016 by № 917/29047 approved the provision on the criteria of Olympic sports priority in Ukraine, according to which by the Order from 14.12.2016 № 4656, 14.03.2017 № 1036, 18.04.2018 № 1703 the prior summer Olympic, team Olympic and winter Olympic sports were approved.

According to the submission of the state administration bodies on physical culture and sport in districts and in Kyiv, the list of priority sports for territories is formed and approved by the Order of Ministry of Youth and Sport from 18.05.2018 № 2273. It takes into account traditions, qualified specialists and sports infrastructure. However, there are many questions regarding the fact of how those priorities in sports at the local level were defined in the districts (e.g. whether medal perspectives of current sportsmen in the future Olympic games have been considered, whether conditions for their training at the local level have been created by the example of those, which athletes have in the sport training centres, as a leading organization form to train Olympians abroad). Ministry of Youth and Sport takes measures to define the priority of the Olympic sports in Ukraine. Particularly, Ministry of Youth and Sport mentioned in the letter from 31.05.2018 № 4135 to the regional state administrations, that it orients its activity to introduce the strategic management into the processes control system, oriented to the Olympic sports priority, through their resource provision, capital investment involvement for material and technical support of the Olympic sport, including through State Programs of the Regional Development, priority financing of the Olympic sports. However, there is a question, whether it is enough for districts and Kyiv to have new and modern sport buildings according to the above sport priorities (in fact there are no such buildings).

There is a supporting system of the leading coaches in the country. According to the Order of the President of Ukraine from 11.07.2005 № 1071, the famous sportsmen and coaches are paid monthly scholarship in the volume of 15 thousand UAH due to the sports achievements. According to the Resolution of the Cabinet of Ministers of Ukraine from 14.12.2011 № 1286 (with changes), famous coaches, who prepare sportsmen to participate in the Olympic Games, are paid a scholarship in the 
volume of fifteen subsistence minimum for working persons. According to the Resolution of the Cabinet of Ministers of Ukraine from 12.04.2017 № 255, the main and the senior coaches of the domestic team of the national teams of Ukraine are paid monthly award in the volume of $100 \%$ of the official salary. Besides, according to the results of sportsmen's performance in the official international competitions, coaches are paid money award in the volume, established by the Resolution of the Cabinet of Ministers of Ukraine from 4.02.2016 № 91. There is a question again, how the coaches' effective activity in the low training link is stimulated.

It is important that projected laws have been already developed for the approval by Verkhovna Rada of Ukraine. If they are approved, they will help develop the physical culture and sport, involve additional financing sources, and regulate sport patrons' rights at the legislative level. these projected laws, which after their approval will be laws of Ukraine: "On patronship in the physical culture and sport» (from 19.07.2017 № 6770), «On making changes to the Tax Code of Ukraine regarding patronship in the physical culture and sport» (from 19.07.2017 № 6771), «On making changes to the article 287 of the Customs Code of Ukraine regarding patronship in the physical culture and sport» (from 19.07.2017 № 6772).

Considering above mentioned, noted, that significant defect of all mentioned managerial influences is their nonsystematicity, free selectivity of questions, which are put by the governing body to the agenda, insufficient efficiency of the macro pedagogical impacts set, used by the Ministry of Youth and Sport of Ukraine. The macro pedagogical regulators define the efficiency (non-efficiency) of the Olympic sport reform. The sport reform includes qualitative changes in the long-term training system of sportsmen, who are engaged in the priority forms and methods of the educational and training process, when extending the scientific recommendations, own positive experience and involving the most progressive things by colleagues abroad, our sport organizations, influenced by the effective state government of the sport sphere, will have features of the best sport-oriented organizations, will have success at the market.

One of the macro pedagogical instruments in the management strategy regarding the further development of sport has to be the rating, which defines the best districts and federations on the Olympic sports development. This rating is used and essentially improved by the Ministry of Youth and Sport. Today, the rating is formed by the number of scores (Olympic sports, 2013), which are given for sportsmen's performances in the sports competition according to the table of the Olympic sports rating identification in Ukraine (Table 6).

It falsely orients participants being represented in such a way, even if some edits are made. First, the main results of success in this rating have to be given in the year of Olympiad for the work, done for sportsmen's training during the summer and winter Olympic cycles. In other years the rating assess has to be intermediate. Second, it seems that developers of the rating do not take into account the distinctive circumstance, that non-official team scoring of the countries-participants of the Olympic Games takes into account only 1-3 places, but not 1-12 places, i.e. medal success. From the proposed scheme of the rating use, it is obvious that in this case, and maybe in other cases, the Ministry of Youth and Sport, which declares «introduction of the strategic management», does not consider (does not understand, does not know, or does not use in the interests of the situation) peculiarities of the state regulation regarding such complicated sphere of the public life. This sphere is the system to train sportsmen in the Olympic kinds of sports.

«Olympic kinds» means that first twelve places, but medal success of the representatives from districts and Kyiv, and national federations should be taken as the indicator of the Olympic sports development according to results of the Summer and Winter Olympic Games. It is known that the way to success in the Olympiad goes through successful performances of sportsmen at the European Championships and World Cups. The mentioned indicators to form the rating in the year of the Olympic Games by medal success at the Olympiads, and in other years in the Olympic cycle in the European Championships, World Cups and 
Championships cannot be taken into account to evaluate achievements on Olympic sports development in districts, in Kyiv and federations. As for the junior sportsmen's success, it helps force their training.

Table 6. The Olympic sports rating in Ukraine

\begin{tabular}{|c|c|c|c|c|c|c|c|c|c|c|c|c|c|c|c|}
\hline \multirow[b]{2}{*}{ Place } & \multirow{2}{*}{ 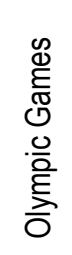 } & \multirow{2}{*}{ 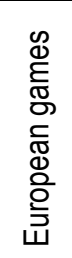 } & \multirow{2}{*}{ 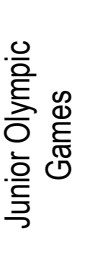 } & \multicolumn{3}{|c|}{ Championship } & \multicolumn{3}{|c|}{$\begin{array}{l}\text { Championships } \\
\text { among youth } \\
\text { and juniors }\end{array}$} & \multicolumn{3}{|c|}{$\begin{array}{c}\text { Championship } \\
\text { among } \\
\text { youngsters }\end{array}$} & \multicolumn{3}{|c|}{$\begin{array}{l}\text { Cups (adults, } \\
\text { final) }\end{array}$} \\
\hline & & & & 읗 & $\begin{array}{l}\text { ֻे } \\
\text { 를 }\end{array}$ & 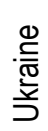 & 읗 & 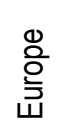 & 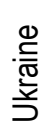 & 은 & $\begin{array}{l}\text { 을 } \\
\text { 플 }\end{array}$ & 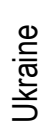 & 읗 & 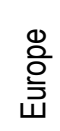 & 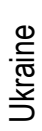 \\
\hline 1 & 5000 & 2500 & 750 & 2000 & 1000 & 100 & 1000 & 500 & 50 & 500 & 250 & 25 & 1000 & 500 & 50 \\
\hline 2 & 4000 & 2000 & 600 & 1600 & 800 & 80 & 800 & 400 & 40 & 400 & 200 & 20 & 800 & 400 & 40 \\
\hline 3 & 3500 & 1750 & 500 & 1300 & 700 & 70 & 650 & 325 & 35 & 325 & 165 & 18 & 700 & 350 & 35 \\
\hline 4 & 3000 & 1500 & 375 & 1000 & 600 & 60 & 500 & 250 & 25 & 250 & 125 & 13 & 600 & 300 & 30 \\
\hline 5 & 2500 & 1250 & 300 & 800 & 500 & 50 & 400 & 200 & 20 & 200 & 100 & 10 & 500 & 250 & 25 \\
\hline 6 & 2000 & 1000 & 250 & 700 & 400 & 40 & 350 & 175 & 18 & 175 & 85 & 9 & 400 & 200 & 20 \\
\hline 7 & 1500 & 750 & 225 & 600 & 300 & 30 & 300 & 150 & 15 & 150 & 75 & 8 & 300 & 150 & 15 \\
\hline 8 & 1000 & 500 & 200 & 500 & 250 & 25 & 250 & 125 & 13 & 125 & 65 & 7 & 200 & 100 & 10 \\
\hline 9 & 800 & 400 & 150 & 400 & 200 & 20 & 200 & 100 & 10 & 100 & 50 & 5 & 150 & 75 & 8 \\
\hline 10 & 600 & 300 & 100 & 300 & 150 & 15 & 150 & 75 & 8 & 75 & 35 & 4 & 100 & 50 & 5 \\
\hline 11 & 400 & 200 & 75 & 200 & 100 & 10 & 100 & 50 & 5 & 50 & 25 & 3 & 50 & 25 & 3 \\
\hline 12 & 200 & 100 & 50 & 100 & 50 & 5 & 50 & 25 & 3 & 25 & 15 & 2 & 25 & 10 & 2 \\
\hline
\end{tabular}

Source: developed by the authors.

In the Summer Olympic Games in Rio de Janeiro 206 athletes, who were in the Ukrainian team, won only 2 gold medals (while the teams of such small countries as Hungary and Croatia 8 and 5 gold medals respectively). None of 21 participants, who represented Donetsk district, could win any medal in the Games. It also concerns all 8 sportsmen from Kherson district, all 6 athletes from Kropyvnytsky etc.

In the Winter Olympic Games in Pyeongchang-2018 Ukraine won 1 gold medal. At the same time Netherland and Belarus, which sent 33 athletes as Ukraine did, had 8 gold medals (in total 20), 2 gold and 1 silver respectively.

Implementation of the specified instrument of the macro pedagogical regulation is a great innovation. It must be started from the new Olympic cycle during 2021-2024. But it is necessary to inform sports leaders and presidents of federations about this innovation. During this time specialists in the centre and at the local level through workshops with their participation, preparation and specified order dispatch to define the rating, understand the essence of such instrument and have to be mobilized.

It is clear that the separate improved rating will not raise the Ukrainian sport. Other actions to form the training system are required. Through the example of leaders' attraction to the new rating, can describe how the macro pedagogical instrument can work in the essential development of the Olympic sports in Ukraine.

In this way, the systematically (comprising all main elements of practice to train Olympians by complex influences), competently (considering all most essential circumstances, related to the implementation of the managerial decisions given by Ministry of Youth and Sport at the local level), working for perspective (to understand that managerial decisions on state regulation require long-term performance), carrying out the effective and systematic control, the strategic management are introduced in the system of processes 
regulation. Right actions of Ministry of Youth and Sport of Ukraine, which in fact are not strategic, as everyone sees, cannot provide the Olympic sport reforming.

Conclusion. The necessity to reform the sportsmen's training system in the Olympic sports is defined by the current stable negative tendency to decrease results of Ukrainian sportsmen's performances in the largest authoritative international competitions, particularly, in the Summer and Winter Olympic Games.

Activity of the state administration border, that is Ministry of Youth and Sport of Ukraine, regarding implementation of the «Strategy to form modern system of the Olympic training for the period up to 2020», approved by the resolution of the Cabinet of Ministers of Ukraine from 3.06.2009 № 592-p, and during the next years has to be of the strategic character by its orientation and essence.

The absence of strategy inactivity of the Ministry of Youth and Sport in the Olympic sports development from one to another Olympic cycle is objectively caused by the fall of leading Ukrainian sportsmen's performances results in several times from 1996 to 2016 in Summer and Winter Olympic Games. Implementation of the strategic management, that will not be substituted by the new version of the Law of Ukraine «On physical culture and sport», and without which it is impossible to set the problem regarding Olympic sport reform in Ukraine, is an objective necessity and challenge for the Ministry of Youth and Sport leaders. The strategic management provides the change of the whole paradigm of influences on the sporting sphere in this state administration body. Particularly it includes the distribution of functions on sports development management in the centre and at the local levels, practice to make managerial decisions with experts' involvement, the creation of new organizational forms of the modern sport, such as training centres etc. At the same time, the change of paradigm to regulate the Olympic sports development is impossible without development and implementation of the macro pedagogical influence instruments on the practice to train sportsmen in districts, in Kyiv and in the national federations. The talented sportsmen are found and trained in such spot-oriented organizations. Most problems of the sports training have to be solved by these qualitative developed instruments.

\section{References} $1-17$.

Baade, R. A. (1996). Professional sports as catalysts for metropolitan economic development. Journal of urban affairs, 18(1),

Bojchenko, V. S. (2017). Features of organizational and economic provision of forming the management of the development of the old industrial region. Marketing and management of innovations, 1, 271-279.

Bordyugova, G. S. (2009). Place of sports law in the national legal system. Pravo Ukrayiny, 3, 144-147.

Esentaev, T. K. (2016). Environment training and competitive activity. Kiev. 192.

Garo, G. O., Kushnir, O. O. (2018) Sporting rights: review of national legislation and international standards. Retrieved from: http://protokol.com.ualru/sportivne_pravo_oglyad.natsionalnogo_zakonodavstva_imignarodnih_standartiv pdf.

Girginov, V., \& Hills, L. (2008). A Sustainable Sports Legacy: Creating a Link between the London Olympics and Sports Participation. The International Journal of the History of Sport, 25(14), 2091-2116.doi:10.1080/09523360802439015

Grynkevych, O. S., Lutchyn, N. P. (2017). Analysis and modeling of the processes of internationalization of higher education in the context of innovation development. Marketing and management of innovations, 3, 314-325.

Johnson, A. T. (1982). Government, opposition and sport: The role of domestic sports policy in generating political support. Journal of sport and social issues, 6(2), 22-34

Kordzaya, N. R. (2017). Perception of social advertising by the population of Ukraine. Marketing and management of innovations, 3, 158-164.

Lyulyov, O., Chygryn, O., and Pimonenko, T. (2018). National Brand as a Marketing Determinant of Macroeconomic Stability. Marketing and Management of Innovations, 3, 142-152. http://doi.org/10.21272/mmi.2018.3-12

Manzenreiter, W., \& Horne, J. (2005). Public policy, sports investments and regional development initiatives in Japan. In The political economy of sport (pp. 152-182). Palgrave Macmillan, London.

Nielsen, K., \& Storm, R. K. (2013). Is India the Exception?: The Impact of Economic Growth on the Competitiveness of National Elite Sport Systems. Birkbeck Sport Business Centre Research Papers, 6(1).

Olympic sports (2013). The order of the Ministry of Youth and Sport of Ukraine: On approval of the Regulations on the rating of the Olympic sports, № 667 from 21.10.2013. 


\section{Prykhodko, O. Tomenko. Innovative Approach to the Strategic Management of the Olympic Sport Reform in Ukraine}

Pavlenko, Yu., Kozlova, N. (2013). Scientific and methodological support for the training of athletes in the Olympic sport. Nauka v olimpiyskom sporte, 2, 73-79.

Pavlenko, Yu., Kozlova, N. (2013). Sports training centers in the system of training athletes. Nauka v olimpiyskom sporte, 3 , 81-86. 680.

Platonov, V. N. (2015). The system of training athletes in the Olympic sport. General theory and its practical applications. Kiev.

Platonov, V. N., Pavlenko, Yu. A., Tomashevskyi, V. V. (2012). Training athletes of the different countries for the Olympic Games. Kiev, 336.

Prykhodko, V. V. (2014). The role of macro-pedagogy in creating the concept of sports reform in the conditions of modern Ukraine. Sporty vnyi visnyk Prydniprov'ya, 1, 179-181.

Prykhodko, V. V. (2017). Direction, content and principles of the sport reform of the highest achievements in Ukraine. Sporty' vnyi visnyk Prydniprov'ya, 1, 308-313.

Prykhodko, V. V., Nomenko, O. A., Mykhailychenko, O. V. (2016). Improvement of the organization and content of scientific research on physical culture and sport in Ukraine as an important prerequisite for their reform. Pedahohichni nauky: teoriya, istoriya, innovatsiyni tekhnolohiyi, 3 (57), 419-429.

Sakhnovskyi, K., Fomin C. (2002). To the results of performances of athletes of Ukraine at the XIX Olympic Winter Games. Nauka v olimpiyskom sporte, 3-4, 24-31.

Shynkaruk, O. (2012). Features of the Olympic training of athletes in foreign countries. Fizychne vykhovannya, sport i kul'tura zdorov'ya v suchasnomu suspil'stvi, 1 (17), 126-130.

Sozansky, Kh. (2003). Optimization strategy of training highly qualified athletes. Vestnik sportivnoy nauki, 15-18.

The concept of strategic government management. Retrieved from: https://studbooks.net/1063619/pravo/strategicheskoe upravlenie_suschnost_mehanizmy.

Ukraine at the Olympics. Retrieved from: https://uk.wikipedia.org/wiki/Україна_на_Олімпійських_іграх.pdf.

Volik S. V. (2013). Financial components of functioning of professional football clubs of Ukraine. Slobozhanskiy naukovosporty' vnyi visnyk, 5 (38), 54-58.

Zaharchyn, G. M., Sklyaruk, T. V. (2017). Transformation of new values in the management category. Marketing and management of innovations, 2, 121-128.

В. В. Приходько, докт. пед. наук, профресор, Придніпровська державна академія фізичної культури і спорту (Україна);

О. А. Томенко, докт. наук з фіз. вих. та спорту, професор, Сумський державний педагогічний університет ім. А. С. Макаренка (Україна).

Інноваційний підхід до стратегічного управління реформою олімпійського спорту в Україні.

Основною метою дослідження є обгрунтування необхідності використання інноваційних підходів стратегічного управління з боку Міністерства молоді та спорту України під час підготовки і проведення реформ системи підготовки спортсменів в олімпійських видах спорту. Авторами визначено необхідність застосування інновацій при формуванні системи менеджменту підготовки спортсменів-олімпійців в Україні. Доведено, що дана система в сучасних умовах не може ефективно функціонувати через існуючу стабільно-негативну тенденцією до зниження результативних виступів українських спортсменів на літніх та зимових Олімпійських іграх. Враховуючі наявні негативні тенденціх, впровадження "Стратегії формування сучасної системи олімпійської підготовки на період до 2020 р.» має носити за своєю спрямованістю і змістом стратегічний характер, коли стратегічне управління передбачає зміну усіё парадигми впливів на сферу спорту у провідному органі державного управління. Однією з гіпотез статті $€$ наявність прямого причинно-наслідкового зв'язку між економічним зростанням та кількістю перемог українських спортсменів на Олімпійських іграх. Результати регресійного аналізу зв'язку між темпами зростання валового внутрішнього продукту на душу населення та загальною кількістю призових місць на Олімпійських іграх для України в період 1994-2016 рр засвідчили відсутність прямої та статично значимої залежності між цими двома індикаторами. Авторами у межах інноваційного підходу запропоновано: розподілу функцій з управління розвитком спортом у центрі і на місцях; проведення практики розробки управлінських рішень з залученням експертів; створення нових організаційних форм сучасного спорту, таких як тренувальні центри; розробка і використання інструментів макропедагогічного впливу на практику підготовки спортсменів в областях, м. Києві і національних федераціях.

Ключові слова: інноваційний підхід, стратегічне управління, спорт вищих досягнень, олімпійський спорт, система підготовки спортсменів.

Manuscript received: 15.01.2019.

(c) The author(s) 2019. This article is published with open access at Sumy State University. 